\title{
SPECIAL LECTURE
}

\author{
Drug Delivery System
}

\section{ドラッグデリバリーシステムとマイクロマシン}

\section{高倉喜信*1)，丸山一雄 ${ }^{* 22}$ ，横山昌幸*3)}

Drug delivery systems and micromachines

This review explains correlation between drug delivery systems and micromachines with focusing on drug targeting. Micromachines are mm order-sized or smaller machinery for functions in microscopic scales. "Drug targeting machine" has been described in the micromachine field as one "dream machine" working in living bodies. On the other hand, this dream has been achieved to a considerable extent in the DDS field using nano-sized carrier systems such as liposomes, synthetic and natural polymers. These carriers can be recognized as molecular machines that made from macromolecules or made by association of molecules. This review summarizes recent advances in nano-sized drug carriers and the future perspective of drug carrier research and its developments in terms of nanotechnologies.

Yoshinobu Takakura*1), Kazuo Manuyama*2), Masayuki Yokoyama*3)

key words : drug delivery, drug targeting, micromachine, nano technology, drug carrier

\section{ドラッグデリバリーとマイクロマシン}

マイクロマシン1)とは通常メートルやセンチメー トルオーダーの機械のサイズを大幅に小さくし，大 きさ数 $\mathrm{mm}$ 以下の高度な機能要素から構成された 微小な機械のことである。このような微小な機械を つくる目的は (1) 微細な作業を行う, (2) 省エネル ギーである. (1) の微細な作業のなかで, 体腔内や血 管内で用いる医療分野への応用には大きな期待がか けられている.このマイクロマシンとドラッグデリ バリーとの接点を検討し, そこから将来の研究・開 発の展望をまとめたのが本総説である.

ドラッグデリバリーシステムの研究と開発に係わ る大部分の者にとって, 通常はあまり係わることの

(1) Department of Biopharmaceutics and Drug Metabolism, Graduate School of Pharmaceutical Sciences, Kyoto University, Sakyo-ku, Kyoto 606-8501 京都大学大学院薬学研究科病態情報 薬学分野

Offprint requests to : Yoshinobu Takakura, $\mathrm{Ph} . \mathrm{D}$.

*a) Department of Pharmaceuticics, School of Pharmaceutical Sciences, Teikyo University, 1091-1 Suarashi Sagami-cho, Tsukui-gun, Kanagawa 199-0195 帝京大学薬学部楽剂学教室 Offprint requests to : Kazuo Maruyama, $\mathrm{Ph}$. D.

*3) Institute of Bimedical Engineering, Tokyo Women's Medical University Kawada-cho 8-1, Shinjuku-ku, Tokyo 162-8666 東 京女子医科大学医用工学研究施設

Offprint requests to : Masayuki Yokoyama, $\mathrm{Ph}$. D.
ないマイクロマシンとの関連を今回探索するきっか けとなったのは, 2000 年 11 月 8 日(水) 10日に行 われた第 11 回マイクロマシン展 ${ }^{29} に$ 日本DDS 学会 としてのパネル展示を行ったことによる. ドラッグ デリバリーとマイクロマシンの両領域が共有する接 点として，本著者がリストアップしたのは以下の 3 項目である.

（a）ミクロなカテーテルからの血管内，組織内 への薬物放出

(b) 半導体マイクロパターニングを利用したミ クロな薬物放出デパイス

（c）ナノキャリアを利用した薬物ターゲティン グ

本著者らは, この 3 項目のうち, 研究がもっとも 盛んに行われており，かつマイクロマシン展の来場 者にもっとも興味を引きやすいと考えられた，(c) についてのパネル展示を行った。本総説はマイクロ マシンという観点から薬物のターゲティングを再整 理し,さらに末来の研究・開発の展望を探った。

マイクロマシンの一つの未来構想あるいは夢とし て語られることの多いもののひとつが“薬物ターケ゚ ティングマシン”である。もし，1966 年に作製され た SF 映画“ミクロの決死圈”をご存じの方は，そこ 


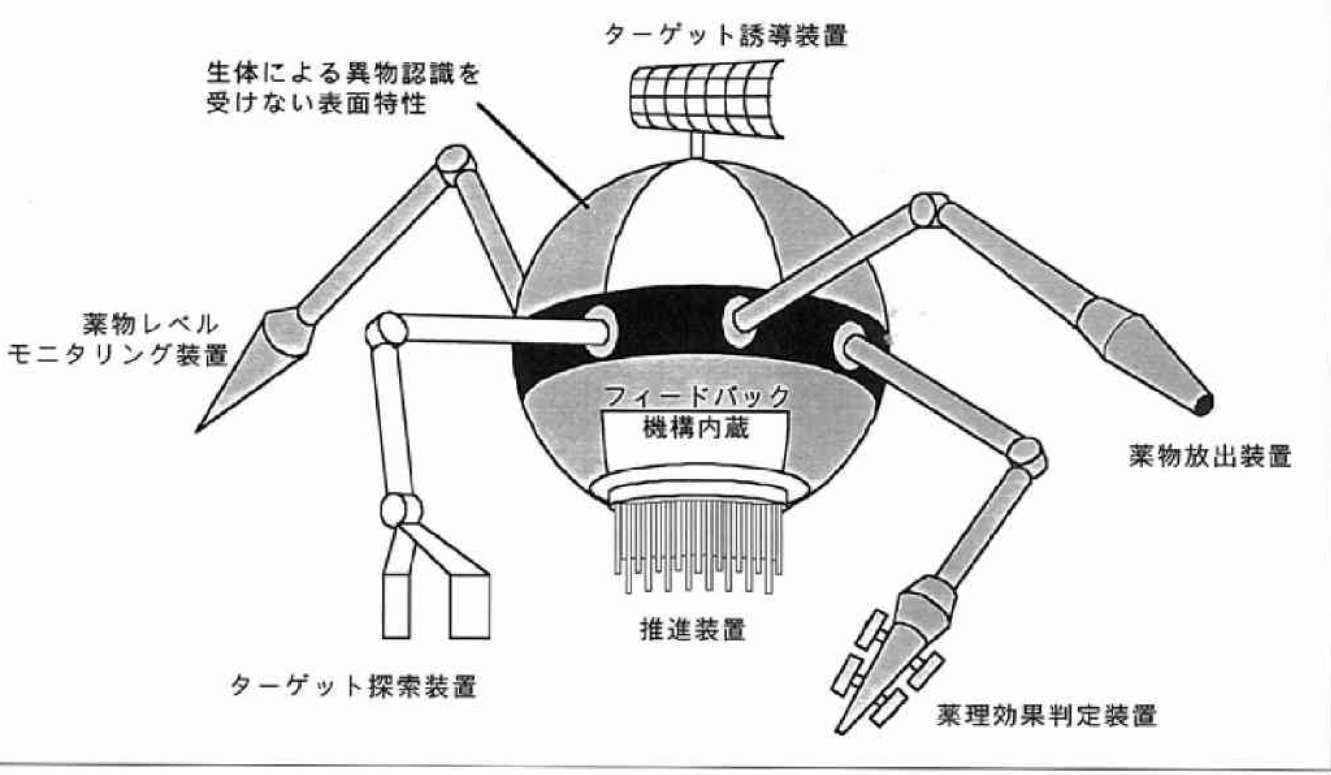

図 1 ト゚ラッグターゲティングマシンの概念

で描かれた $5 \mu \mathrm{m}$ 程度に縮小化された潜水艦が血液 や体液中を移動して脳内の血栓を治療する場面が思 い起こされることと思う。この映画では治療にレー ザー光線を用いているのだが，これを薬物としたの がまさに“薬物ターゲティングマシン”である。実 際に金属を用いた可動性薬物カプセルをつくろうと するマイクロマシンの研究は行われることはなかっ たが，図1の“薬物ターゲティングマシン”の概念図 に示したシステムは金属ではなく，高分子や脂質な どのマテリアルを用いることでかなりの要素が現実 のものとなっている，次節以降で，図１に描かれた “薬物ターグティングマシン”を念頭に, 現時点まで の実現と将来展望をまとめた。

\section{薬物ターゲティングマシンに必要な因子 ${ }^{3,4)}$}

マイクロマシンが薬物を搭載して生体内の標的に たどり着くために必要な基本的因子としては, (1) 大 きさ，(2) 生体適合性の二つがあげられる.

全身投与されたマシンがその活躍の場である生体 内において標的組織に向う際には, 主に全身に張り 巡らされている血管内を血流に乗って移動すること が想定される，生体内を自由に移動するためには， 第一にマシンの大きさが各組織に存在する毛細血管 の内径より小さいことが必要条件となる. 毛細血管
は組織によらずほほ直径が $5 \mu \mathrm{m}$ 程度といわれてお り，基本的にはこの值がマシンの上限サイズとなる が, 上述の “ミクロの決死圈” に登場する潜水艦は ちょうどこのくらいの大きさに設定されていた.

このディメンジョンは, 血液細胞の大きさに対応 しており, 代表的な赤血球は直径約 $7.5 \mu \mathrm{m}$, 厚さ 2 $\mu \mathrm{m}$ の大きさをもつ円盤状の細胞であるが(図 2), 毛 細血管部分を通る際にはその直径より若干大きいた め血管壁に接触するが，柔軟性を有するため多少の 変形を伴い通過することが知られている。これより 大きいサイズで硬いマシンを用いた場合には, 毛細 血管床に塞栓を起してしまうが，これは原始的な方 法ではあるものの癌の化学塞栓療法に代表される ターゲティングが可能である。この場合には, マシ ンは塞栓すべき臟器のすぐ上流の動脈から投与すれ ばよい、しかしながら，より遠隔部位にある標的を 目標とする場合にはもつとサイズの小さいマシンが 必要となる. $5 \mu \mathrm{m}$ より小さい場合には, 血液中に保 持されうるが, 多くの場合, 異物として肝臟, 脾臓 等の細網内皮系に速やかに補足されてしまうため長 時間血管内を循環することができない，後述するよ うにこれを左右するのはマシンの生体適合性であ る.

一方, 標的組織でマシンが血管外一出て標的細胞 にアクセスするためには，さらに毛紐血管の乿間よ 


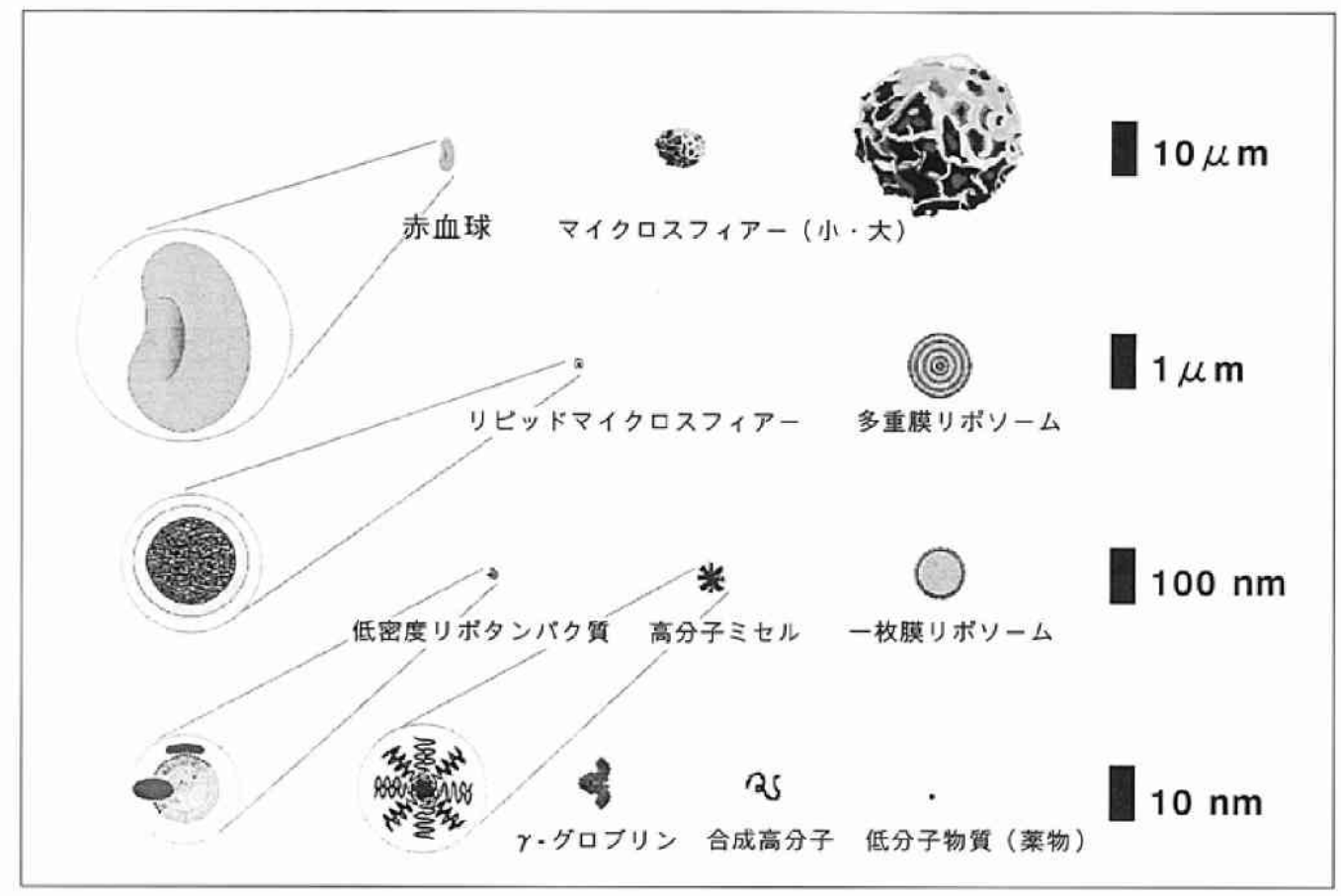

図 2 ドラッグキャリアのサイス

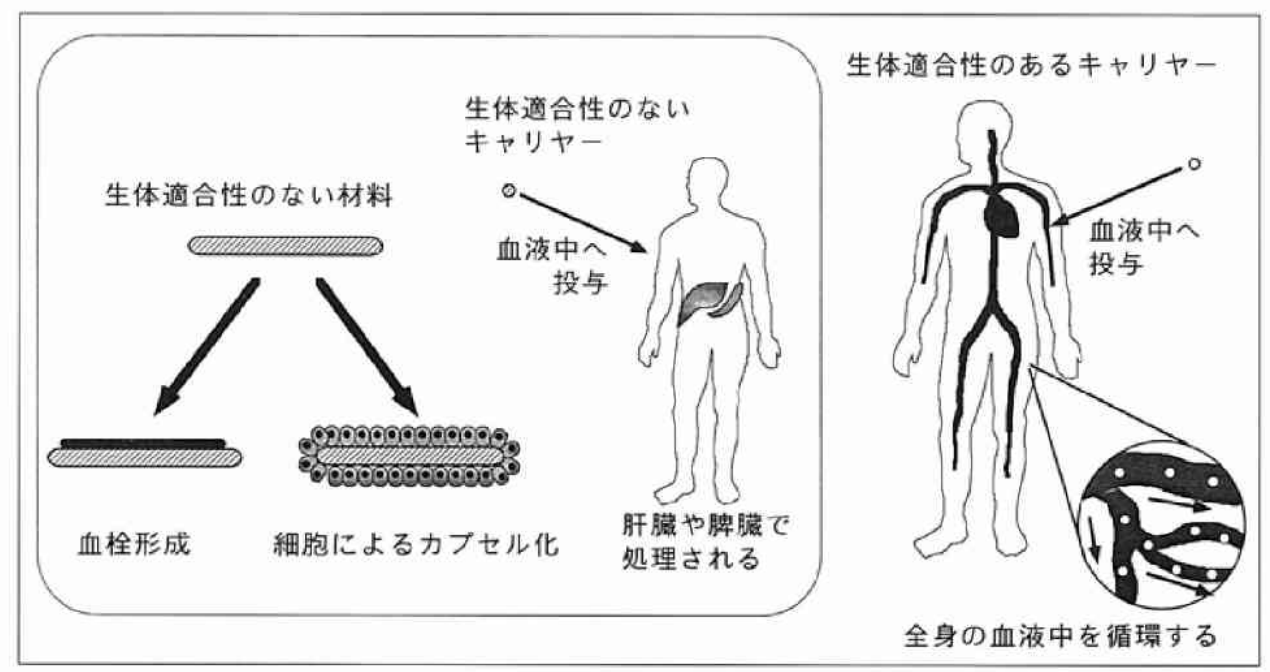

図３ドラッグキャリアの表面材料の生体適合性

り小さいサイズが要求されるが，肝臟類洞のフェネ ストラ(空)のサイズは約 $100 〜 200 \mathrm{~nm}$ ，毛細血管の 透過性が立進している腫瘍組織においても最大数百 $\mathrm{nm}$ 程度であるため, ナノスケールの大きさが必要 である，図 2 に示した既存の薬物キャリアのサイズ を参照して頂きたい.

もう一つの重要な因子である生体適合性はマシン の表面特性に大きく依存している(図 3)。血管内に 投与されたあと, 最初に遭遇する血液成分との相互
作用は回避すべきもつとも重要な因子と考えられ る。たとえば，補体などによるオプソニン化などは 細網内皮系による領食を促進してしまうので絶対避 けなくてはならない，細網内皮系の細胞による直接 認識もなるべく受けにくいように設計する必要があ る.このためには, ナノマシン表面の疎水性や電荷 などの物理化学的性質の最適化を実現しなくてはな らない，サイズが多少大きくても血液中を安定に循 環する赤血球の表面が弱い負電荷に帯電している現 
象，ポリエチレングリコール修飾が高分子や微粒子 のステルス化を可能としている事実などが，こうし た薬物ターゲティングナノマシンを開発する際の何 らかの指針となるかもしれない.

\section{ドラッグターゲティングの現状 ${ }^{5)}$}

現在, 薬物ターゲティングに利用される微粒子型 キャリアは, 調製に用いられる素材の面から, 脂質 分子の集合体(リポソーム, リピッドマイクロスフィ アー)と高分子マトリックスからなるマイクロス フィアーや高分子ミセルに大別できる。これら微粒 子型キャリアの体内動態は, キャリアの物理化学的 性質と先に述べた生体各部位の形態的・生理的特性 とのバランスによって規定される.

つまり,こうしたキャリアのターゲティングは, 血液循環作用, 拡散および容積流輸送という生体の 機能を受け身に利用していることになり,“パッシブ ターゲティング(passive targeting)”6)とよばれる. これに対して,このようなキャリアにさらに特殊な 仕組みを付け加え，体内動態を積極的に制御する ターゲティングを, “アクティブターゲティング (active targeting)”とよんでいる，後者には，抗体 やレクチンなど特定細胞に親和性を有する物質を利 用する方法や，磁力のような体外から作用する物理 的な力を利用してキャリアを誘導する方法がある.

微粒子キャリアの場合, 固形癌へのパッシブター ゲティングの戦略となっているのが, EPR 効果であ る.これは Enhanced Permeability and Retention effect の略で, 1986 年に熊本大学の前田, 松村が提 唱したものである ${ }^{7.8)}$. EPR 効果とは, 腫瘍における 微小脈管レベルでの特異性(次の(1)から(4))にもとず く高分子やリピッド・リポソーム・高分子微粒子な どの特異的な動態で, それらは血中から癌組織間質 へ漏出し,いったん出たものは管腔側に戻りにくく 蓄積する現象である.

(1) 新生血管の増生

(2) 腫瘍血管の機能と構造上の欠陥：腫瘍血管は 血管作動性ペプチドであるアンジオテンシン II に応答しない(これが, 昇圧化学療法の基礎と なっている. 電子顕微鏡レベルでも指摘されて
いるように, 腫瘍血管は異常な分岐と歪曲をも つ不規則で脆弱な構造をしている.

(3) 血管透過性の著明な元進と高分子物質の腫瘍 血管を介する回収の欠如

(4)リンパ系を介する回収の欠如：腫瘍組織は非 常にリンパ管にそしい.

実用化されている脂質分子の集合体からなる微粒 子キャリアには, 脂肪輸液製凨の分散相である油滴 微粒子をプロスタグランジンやステロイド剤などの 脂溶性薬物のキャリアに利用したリピッドマイクロ スフィアーと，リン脂質を基本とする脂質二重層か らなる閉鎖型小胞のリポソームに抗真菌刘アムホテ リシン $\mathrm{B}$ や抗癌剤ドキソルビシンを包含させたリ ポソーム製剤がある、ところで, 微粒子キャリアは, 異物処理機構によって肝臟を中心とする細網内皮系 細胞による頜食を受けるため, 全身レベルでのター ゲティングを期待する場合, 積極的な異物処理機構 の回避が非常に重要な因子である、リポソームでは 表面をポリエチレングリコールで被覆する試みが行 われ成功を収めている,

このようなポリエチレングリコール修飾リポソー ムは“ステルスリポソーム”あるいは“ニンジャ(忍 者)リポソーム”と名付けられている. $100 \mathrm{~nm}$ 前後の ステルスリポソームは細網内皮系による取り込み回 避の結果, 血中滞留性が高まり, 血管透過性が元進 している炎症部位, 感染部位など, 特に EPR 効果に よって癌組織に集積するようになる。 また, 集積し たリポソームからハイパーサーミアなどの熱処理に よって包含薬物が高濃度に放出されるように工夫さ れた温度感受性のステルスリポソームも開発されて いる11). ステルスリポソームの表面に抗体を付加し たステルスイムノリポソームでは, 血中带留性を損 なわないように抗体の Fab'フラグメントが使用さ れ, “パッシブターゲティング”で癌組織に集積させ, そこで癌細胞を認識して細胞表面に結合あるいは細 胞内にエンドサイトーシスで取り込ませる“アク ティプターゲティング”が可能である ${ }^{12}$. アンテナに 相当する抗体の Fab'フラグメント組み込み, 生体 適合性を具備したステルスイムノリポソームは, ターゲティングナノマシンのプロトタイプといえる もので, 生理活性蛋白や遺伝子などを細胞内に送達 
キャリアとして, 今後重要なシステムになるものと 考えられる。現在, ドキソルビシンを封入したステ ルスイムノリポソームが，前臨床試験評価段階にあ る。

合成高分子を用いながら，高分子を会合させるこ とでよりサイズの大きいサイズのキャリアシステム としたのが高分子ミセルである ${ }^{13,14)}$. 二つの高分子 鎖が直列につながった形のブロックコポリマーを用 いて，薬物を導入した内核と，それをとりまく外殼 の 2 相構造を形成させるものである. 高分子ミセル は通常 20〜100 nm の直径という, 癌へのパッシブ ターゲティングに必要とされるサイズである。図 1 のドラッグターゲティングマシンの概念図で考える と, 高分子ミセルは薬物保持する内側の機構と生体 による異物認識を受けない外側の表面がナノスケー ルで明確に分離できている構造となっている，横山 と片岡らの研究グループ ${ }^{015,16)}$ は, 抗癌剤ドキソルビ シンを内包した高分子ミセルを用いて, 著しい $i n$ vivo 抗癌活性の増進を得, 癌組織への選択性高い集 積を確認した。この高分子ミセルは, 現在, 前臨床 試験評価を目前にした開発が進行中である。

合成高分子を用い，静脈内投与による全身レベル でのパッシブターゲティングでもっとも進んでいる のは, Kopecek, Duncanらによって研究されてい る, ビニル系の水溶性合成高分子である PHPMA をべースにしたシステムである. PHPMA に四つの アミノ酸からなるスペーサーを介して抗癌剤を結合 させたものである。この抗癌剤を高分子に固定して いる化学結合は血液中では安定で, 細胞に取り込ま れたあとリソソーム内の酵素で開裂されて抗癌剂を 放出し，殺細胞効果を発揮するように設計されてい る.この設計は図１のドラッグターゲティングマシ ンの概念図のターゲット探索装置および薬物放出装 置に対応する.このPK 1 は, イギリスにおいて第 1 相が終了し，臨床第 2 段階を実施中である ${ }^{17,18)}$.

スマンクス/リピオドール ${ }^{87}$ はわが国で開発され， 肝細胞癌の肝動注による治療薬として実用化に至っ た最初のターゲティング型DDSである.これは, 抗 癌性抗生物質ネオカルチノスタチンにブチルエステ ル化したスチレンーマレイン共重合体を結合させ分 子量と眯水性を高めた高分子化医薬スマンクスを油
性造影剂リピオドールに絜濁させた DDSである. この場合, 腫瘍の新生血管の組織学的, 機能的な特 性に従い支配動脈より動注後腫瘍組織内に数力月に わたり滞留する性質を有するリピオドールがターゲ ティングマシンとして機能していると考えられる が，いわゆる EPR 効果をうまく利用したパッシブ ターゲティングに分類される。 またりピオドールと の相性を改善する目的で抗癌㓮の物理化学的性質を 化学修飾により改変し, スマンクスという形にして リピオト゚ールというマシンに薬物を搭載した点も成 功の要因と考えられる.

第 2 節で述べたように，全身投与で積極的に標的 を狙い撃ちするためにはサイズが小さい必要がある が，むしろリピオドールという非常に大きな油滴を 用い，選択的カテーテル法という医療技術を応用し て肝癌細胞が存在するすぐ上流の肝動脈から投与す ることで腫瘍組織への選択性を達成したアプローチ と考えられる.

\section{未来展望}

本総説でマイクロマシンと薬物ターゲティングの 接点を探索したのであるが, 最後にこれからの研 究・開発で重要となるであろうと考えられる二つの キーワードを書き留め, その展望を記しておきたい. まずその第 1 が “ナノテクノロジー”である。本総 説第 2 節に書いたように, 薬物キャリアにはナノス ケールの大きさが必要とされ，近年のナノテクノロ ジーに対する熱望の到来を待つまでもなく, まさに マテリアルを用いたナノテクノロジーを実行してき たのが薬物キャリアの研究そのものであった. 事実, 2000 年 2 月にアメリカのクリントン大統領によっ て唱えられた “Nanotechonology Initiative” ${ }^{199} に は$ ナノサイズのキャリアを用いた薬物ターゲティング が 1 項目として盛り込まれている。ナノスケールで 機能する “マシン”を作製するには，もはや既存の 機械をミニチャ化するは通用せず，マテリアルや分 子を用いたいわば “モレキュラーマシン”が不可欠 である、 21 世紀の開始に当り,ナノテクノロジーの 大きな潮流のなかで, ドラッグターグティングをナ ノテクノロジーの重要な要素であり，もっとも付加 
価值の高い応用の一つとして認識し, 研究と開発を 進めてゆく必要があると確信される。

第 2 のキーワードは, “推進力”である. 図 1 に示 した“薬物ターゲティングマシン”の概念は本総説 の第 2 および第 3 節に記したとおり，そのほとんど の要素が実現している。しかし，ターゲティングマ シンを任意の部位に運搬するための推進力を得るこ とは実現していないといってよかろう。誤解のない ように確認すると，抗体などの active targeting の キャリアは，そのキャリア自体が抗原などの標的部 位に推進力をもって自発的に向かって行くのではな く, 血液や体液中を拡散や容積流輸送によって移動 し，偶然に標的に達したものが結合してその部位に とどまるだけである。また，磁性微粒子を利用した ターゲティングでも, 磁力を与えた部位にキャリア が流されず留まるというのがその本質である。

現在得られている薬物キャリアの移動は血液循環 作用，拡散および容積流輸送という受け身的な現象 に頼らざるを得ない状況である。よって，体内での キャリアの位置, 方向をリアルタイムで測定する技 術を伴って, 薬物キャリアの推進力が得られれば, ターゲティングの大きなブレークスルーとなること であろう.ナノスケールの薬物キャリアであるので, モーターのようなマクロな機械をミクロ化すること で実現することは不可能である，現時点では薬物 キャリアに推進力を与える手段は存在しないが，次 世代のナノテクノロジーの発展に期待するところで ある。（たとえば微生物のもつ鞭毛は直径 $10 \mathrm{~nm}$ の 大きさのモーターとして, 微生物の移動推進力と なっている. 現時点では鞭毛モーターの機能解析を 目指した生科学的, 分子生物学的研究が行われ, こ れをナノスケールの人工物の移動手段とする研究は 行われるには至っていない.）

\section{文 献}

1) マイクロマシンセンターホームページ http://www.iijnet.or.jp/MMC/

2）第11回マイクロマシン展ホームページ http://www. mesago-messefrankfurt.com/micro/

3）橋田 充, 高倉喜信: 生体内薬物送達学, 産業図書, 1994 .

4）高倉喜信：高分子を利用したパッシブターゲティンダ. Drug Delivery System 14:427-431， 1999.

5）橋田 充：ドラッグデリバリーシステム。化学同人, 京都, 1995.

6) 高倉喜信, 丸山一雄, 横山昌幸：パッシブターゲティンダの 意義. Drug Delivery System 14：425-426, 1999.

7) Matsumura $\mathrm{Y}$, Maeda $\mathrm{H}: \mathrm{A}$ new concept for macromolecular therapeutics in cancer chemotherapy: Mechanism and antitumor agent smancs. Cancer Res 46: 6387-6392, 1986.

8) Maeda H, Wu J, Sawa T, Matsumura Y, Hori K : Tumor vascular permeability and the EPR effect in macromolecular therapeutics : a review. J Control Release $65: 271-284,2000$.

9) Klibanov AL, Maruyama K, Huang L : Amphipathic polyethyleneglycols effectively prolong the circulation time of liposomes. FEBS Lett 268: 235-237, 1990.

10) Allen TM, Hansen C, Martin FL et al. : Liposomes containing synthetic lipid derivatives of poly(ethylene glycol)show prolonged circulation half-lives in vivo. Biochim Biophys Acta 1066:29-36, 1991.

11）丸山一雄：リポソームによるパッシブターゲティング. Drug Delivery System 14:433-447, 1999.

12) Maruyama $K$, Takahashi $N$, Tagawa $T$ et al. : Im. munoliposomes bearing polyethyleneglycol-coupled Fab' fragment show prolonged circulation time and high extravasation into target solid tumors in vivo. FEBS Lett 413: 177-180, 1997.

13）横山昌幸：微粒子キャリアによるパッシブターゲティング. Drug Delivery System 14:449-457, 1999.

14）横山昌幸：高分子ミセドラッダキャリアによる固形ガンの ターゲティング治療。生体材料 $16: 276-281 ， 1998$.

15) Yokoyama M, Okano T, Sakurai $Y$, Ekimoto H, Shibazaki C, Kataoka K: Toxicity and antitumor activity against solid tumors of micelle-forming polymeric anticancer drug and its extremely long circulation in blood. Cancer Res $51: 3239-3236,1991$.

16) Yokoyama M, Okano T, Sakurai Y, Fukushima S, Okamoto K, Kataoka K: Selective Delivery of Adiramycin to a Solid Tumor Using A Polymeric Micelle Carrier System, J Drug Targeting 7:171-186, 1999.

17) Cassidy J : Abstracts of 4th International Symposium on Polymer Therpeutics, 2000 p 22.

18) Duncan R, Seymour LW, O'Hare KB, Flanagan PA, Wedge S, Hume IC, Ulbrich K, Strohalm J, Subr V, Spareafico F, Grandi M, Ripamonti M, Farao M, Suarato A : Preclinical evaluation of polymer-bound doxorubicin, J. Contr Rel 19:331-346, 1992.

19) http: //www.whitehouse.gov/WH/New/html/ 20000121_4.html http://www.nano.gov/ 